\title{
FIFTY YEARS OF OIL EXPLORATION IN NIGERIA: THE PARADOX OF PLENTY
}

\section{CHARLES UDOSEN, ABASI-IFREKE S. ETOK AND I.N. GEORGE}

(Received 17 March, 2009; Revision Accepted 19 June, 2009)

\begin{abstract}
It is expected that countries with an abundance of natural resources should prosper. Yet over many years, it has been observed that nations rich in oil, gas, or mineral resources have been disadvantaged in the drive for economic progress. The concept of resource curse which refers to the observation that nations with rich endowments of natural resources [oil as in the case of Nigeria] often dramatically under perform economically relative to what one would expect was used in this study. The methods employed in data collection, primarily from secondary sources include; literature review of NNPC publications, national dailies and newsmagazines; internet reports on OPEC, oil production in Nigeria, etc. Descriptive statistic was used in data analysis.

The results revealed that the oil wealth was initially well applied towards the development of the country. Overtime, successive governments began to mismanage it and a situation like this had given rise to other contemporary oil nations overtaking Nigeria. The consequence is that the early gains of oil disappeared in the face of declining quality of general infrastructure across the country. The growing reliance of the country on oil and gas alone may undermine the democratic structure-rule of law, political stability [as in the case of militancy in the Niger Delta region], government effectiveness and the fight against corruption
\end{abstract}

KEYWORDS: Resource curse, Nigeria, Oil and Gas, GDP, Infrastructure, Corruption

\section{INTRODUCTION}

The history of oil exploration in Nigeria could be traced to the first decade of the last century when oil seepages were seen at Araromi in the present Ondo State. Encouraged by this occurrence a German company, the Nigerian Bitumen Corporation started exploration in that area in 1908 in the very first attempt to search for hydrocarbons in Nigeria. Unfortunately, this pioneering effort did not last long, and the company terminated its operations at the outbreak of the first World War in 1914.

Two decades passed before another major exploration effort was embarked upon. An Anglo -Dutch consortium, came to Nigeria as Shell D' Arcy[ the forerunner of the present Shell Petroleum Development Company of Nigeria] to start exploration activities in 1937 after being awarded the sole concession rights covering the whole territory of Nigeria. Shell D'Arcy's activities were interrupted by the second World War and exploration did not resume until 1947. After many years of search, and investment of over \#30 million, petroleum was discovered at Oloibiri in the Niger Delta in 1956. In 1958, SPDC started oil production and export from the Oloibiri field in the present Bayelsa State at a rate of 5,100 barrels per day. This quantity doubled the following year, and, crude oil production in Nigeria attained its all time peak in January 1979 at the rate of 2.44 million barrels per day.

In 1959, the sole concession rights over the whole country granted to SPDCl was reviewed and extended to companies of other

Charles Udosen, Department of Geography, University of Uyo, Akwa Ibom State, Nigeria

Abasi-Ifreke S. Etok, Department of Geography, Akwa Ibom State College of Arts and Science, Ikono

I.N. George, Faculty of Education, University of Uyo, Akwa Ibom State, Nigeria 
the pace of exploration while at the same time ensuring that the country was not too dependent on one company or nation.

The successes of SPDC encouraged other companies to join in the exploration, and by 1961, Mobil, Gulf, Agip, Safrap [now ELF], Tenneco and Amoseas [now Texaco/Chevron] had joined the explorers, for oil in the onshore and offshore area of Nigeria. The first offshore discovery of petroleum was by Gulf on the Okan structure of Bendel State [now Delta State] in 1964 and many of the new comers also made significant discoveries. Today, license have been granted to indigenous companies in the country to explore, produce and market petroleum products,. However, significant progress have been achieved in the area of marketing of mainly imported petrol and diesel[ fifty years after oil was first struck in 1957]. Local refining of crude oil is now a popular business in the Niger Delta. Its owners and operators are mainly members of the militant groups who because of the huge money they make from the business do not seem to care about the enormous health risks that it entails.

\section{Research Problem}

Common sense and simple economics suggest that countries endowed with an abundance of natural resources should prosper. Yet over many years, it has been observed that developing nations rich in oil, gas, or mineral resources have been disadvantaged in the drive for economic progress.

It is rather unfortunate, that after over fifty years of oil exploration and exploitation in Nigeria, the basic infrastructures seems to be in decay(as roads for instance, are now death traps, power supply is epileptic, poverty is an endemic problem as most of the erstwhile fertile lands in Niger Delta region is infertile and devastated by pollution,. Also, noxious fumes from gas flaring are competing for space in the air. In this direction, therefore, the paradox of resource curse is employed in this study to explain the decline in the competitiveness of other economic sectors in Nigeria.

\section{RESOURCE CURSE CONCEPT}

The term 'resource curse' refers to the observation that nations with rich endowments of natural resources (oil as in the case of Nigeria) often dramatically under perform economically relative to what one would expect. The idea that natural resources might be more of an economic curse than a blessing began to emerge in the 1980's. In this light, the term resource curse thesis was first used by Richard Auty in 1993 to describe how countries rich in natural resources were unable to use their wealth to boost their economies and how, counter-intuitively, these countries had lower economic growth than countries without an abundance of natural resources. Numerous studies, including one by Jeffrey Sachs and Andrew Warner (2003\}, have shown a link between natural resource abundance and poor economic growth. This discontent between natural resource wealth and economic growth can be seen by looking at an example from the oil producing countries. From 1965-1998, in the OPEC countries, gross national product per capita growth decreased on average by 1.3 percent, while in the rest of the developing world, per capita growth was on average 2.2 percent. Research in recent times clearly shows that conflicts among the multi ethnic groups within a country with abundant natural resource, revenue volatility, Dutch disease, excessive burrowing[using natural resources as collateral], and lack of diversification /enclave effects are possible reasons [Bulte, et al, 2005; Ross, [1999]; Humphreys et al,[2007]; , and Sachs, [2001].

In the light of the above, the concept of resource curse is used to ascertain the level of economic growth in Nigeria vis-a-vis the increase in oil revenue over the years.

\section{METHODOLOGY}

Secondary sources of data include; literature review of NNPC publications, national dailies and newsmagazines especially the special edition by Newswatch magazine on'50 years of oil in Nigeria'; internet reports on OPEC, oil production in Nigeria, Resource curse theory etc. Descriptive statistics, graphs and diagrams were generated using computer to show the trends in production levels, proportion contributed by oil to total revenue over time and how the oil wealth is squandered on wasteful/ elephant projects

Data Presentation and Discussion

Before the discovery of oil Nigeria's economy survived and flourished on agriculture. Records indisputably show that 72 percent of the total national output of the economy came from agriculture in 1950, as against $1.1 \%$ from mining and crude oil. The dominant role of agriculture in the nation's fortune continued in 1960 when it contributed $66 \%$ compared with $1.2 \%$ from minerals. Also, at independence in1960 more than $70 \%$ of exports came from agriculture while 
$95 \%$ of the nation's food needs were locally produced.

It is significant to note that the economy, particularly at regional levels, recorded tremendous self-sustaining growth and expansion before crude oil became the mainstay. Revenue from agriculture was appropriately used to build landmark social and economic infrastructure, while providing basic services like education, health, water and electricity supply [Ogunlowo,2008]

The then revolutionary free education programme in the western region was funded entirely from cocoa, rubber and palm oil proceeds. So also were University of Ife [now Obafemi Awolowo University ; the Liberty Stadium, Cocoa House and Western Nigerian Broadcasting and Television services[WNBC/WNTV] Ahmadu Bello University, Zaria and University of Nigeria, Nsukka, UNN were not built foreign grants or loans, but from proceeds from cotton, groundnut, rubber and palm oil. Besides, regional governments set up plantations, farm settlements and cottage industries to service agriculture and provide vast employment opportunities for the people. At the national level, the economy benefited immensely from quality and incorruptible leadership.
However, after the discovery and subsequent production of crude oil for exports in 1956, the story changed and today Nigeria relies solely on crude oil exports [fig 1]. Table 1 indicates a quantum leap in the contribution of crude oil to total export from $2.7 \%$ in 1960 to $73.7 \%$ in 1971 , when the country became a member of the oil cartel-Organization of Petroleum Exporting Countries (OPEC). Since then, the contribution of oil to total export has always been on the increase [except minor fluctuations in 1978, 1982, 1984 and 1986] respectively.

Statistics of Nigeria's earnings from oil support this view. Before the country formally joined the organization as its $11^{\text {th }}$ member in 1971, its crude sold for between 45 cents and 65 cents per barrel. The situation changed after the country pitched its camp with OPEC. For instance, one year after joining the cartel, the average price of Nigeria's Bonny light rose to $\$ 3.22$ per barrel as against 65 cents. The price rose further to $\$ 11.87$ per barrel in 1975 and $\$ 38.82$ in 1980. However, successive years witnessed a rapid decline in the price of Bonny light, which sold for $\$ 15.09$ per barrel in 1988 and a paltry $\$ 12.77$ per barrel in 1998 .

\section{PERCENTAGE OF CRUDE OIL in Nigeria's TOTAL EXPORT[1960.}

\section{7]}

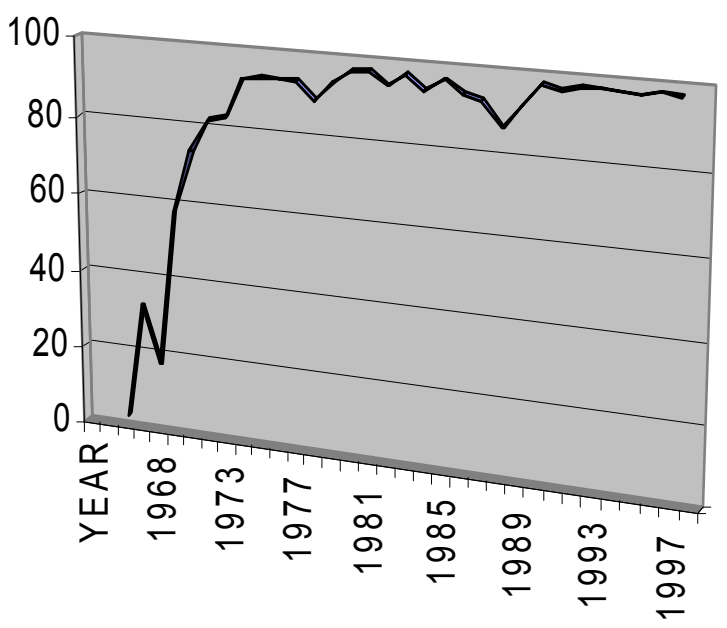

Fig. 1: Percentage of Crude Oil to total Exports in Nigeria 
Table 1: Percentage of Crude Oil in Nigeria's Total Export [1960-1997]

\begin{tabular}{|c|c|}
\hline YEAR & PERCENTAGE \\
\hline 1960 & 2.7 \\
\hline 1966 & 32.4 \\
\hline 1968 & 17.5 \\
\hline 1970 & 57.6 \\
\hline 1971 & 73.7 \\
\hline 1972 & 82 \\
\hline 1973 & 83.1 \\
\hline 1974 & 92.6 \\
\hline 1975 & 93.6 \\
\hline 1976 & 93.6 \\
\hline 1977 & 93.4 \\
\hline 1978 & 89.1 \\
\hline 1979 & 93.8 \\
\hline 1980 & 96.9 \\
\hline 1981 & 97.5 \\
\hline 1982 & 94.3 \\
\hline 1983 & 97.3 \\
\hline 1984 & 93.8 \\
\hline 1985 & 97.1 \\
\hline 1986 & 93.8 \\
\hline 1987 & 92.9 \\
\hline 1988 & 86.7 \\
\hline 1989 & 92.2 \\
\hline 1990 & 97.6 \\
\hline 1991 & 96.6 \\
\hline 1992 & 97.9 \\
\hline 1993 & 97.7 \\
\hline 1994 & 97.4 \\
\hline 1995 & 97.3 \\
\hline 1996 & 98.2 \\
\hline 1997 & $\begin{array}{l}97.6 \\
\text { SBN, } 2000\end{array}$ \\
\hline
\end{tabular}

In a similar fashion, the production levels have been on the increase since 1958 when the country commenced exportation of crude oil [fig.2] 


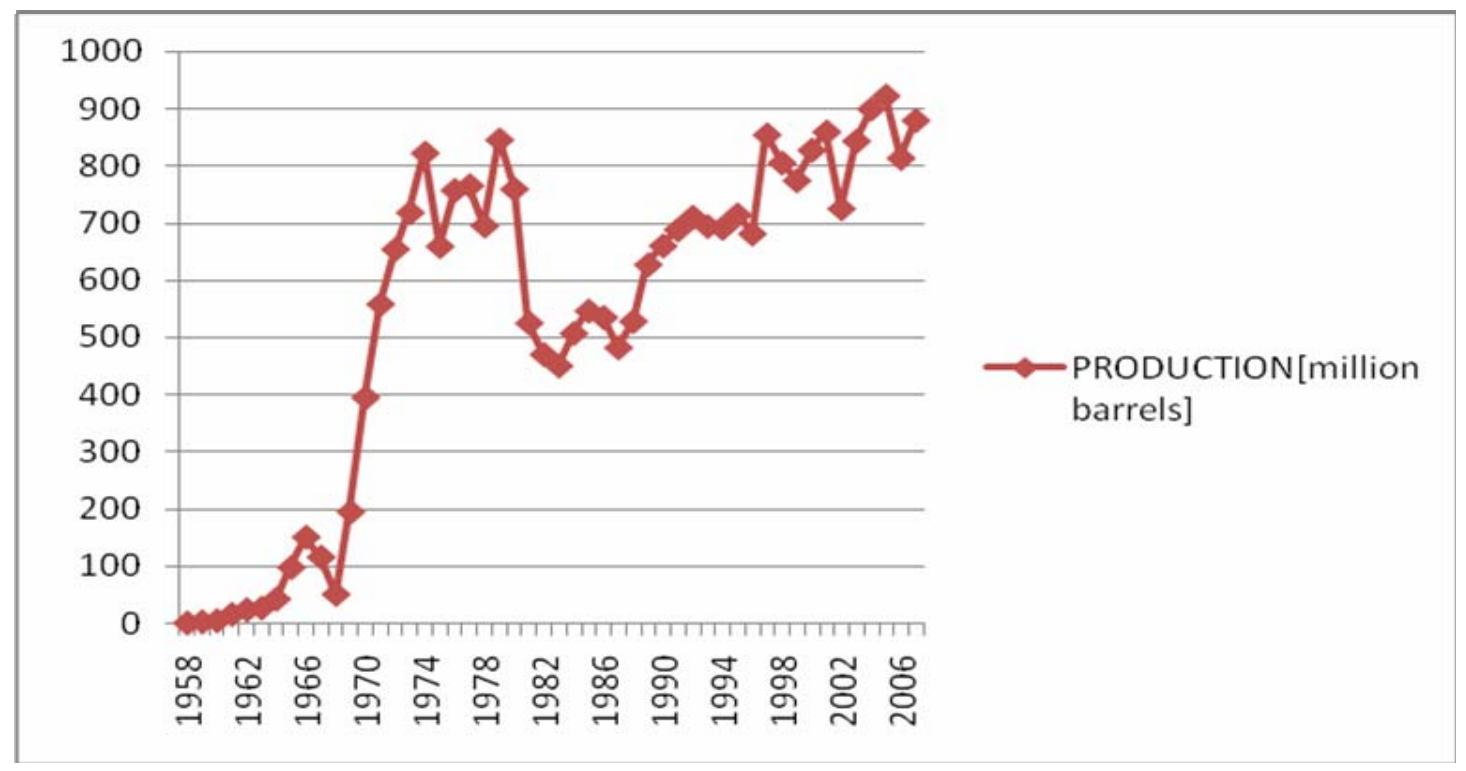

Fig. 2: Estimated Crude Oil Production in Nigeria [1958-2007]

Source: NNPC, Inspectorate and CBN Annual Report and Statement of Account (2008)

Table 2: Estimated Crude Oil Production and Revenue in Nigeria, 1958-2007.

YEAR
1958
1959
1960
1961
1962
1963
1964
1965
1966
1967
1968
1969
1970
1971
1972
1973
1974
1975
1976
1977
1978
1979
1980

$\begin{array}{cc}\text { PRODUCTION[million barrels] } & \text { REVENUE[\#m] } \\ 2 & 0.2 \\ 4 & 3.4 \\ 6 & 2.4 \\ 17 & 17 \\ 25 & 17 \\ 28 & 10 \\ 44 & 16 \\ 99 & 29 \\ 152 & 45 \\ 117 & 30 \\ 52 & 0 \\ 196 & 75.4 \\ 396 & 167 \\ 559 & 510 \\ 655 & 764 \\ 719 & 1016 \\ 823 & 3724 \\ 660 & 4272 \\ 758 & 5365 \\ 766 & 6081 \\ 696 & 4556 \\ 846 & 8881 \\ 760 & 12354\end{array}$


1981

1982

1983

1984

1985

1986

1987

1988

1989

1990

1991

1992

1993

1994

1995

1996

1997

1998

1999

2000

2001

2002

2003

2004

2005

2006

2007

TOTAL

\section{6}

471

451

508

547

536

483

529

628

661

689

711

695

692

715

682

855

806

775

828

860

726

844

900

923

814

880

23,183.9
8564

7815

7253

8264

10915

8107

19027

20934

39131

55216

60314

115392

106192

160192

324548

369190

416811

289532

500000

1340000

1707600

1230900

2074300

3354800

4762400

6109000

6700000

Sources: Petroleum Inspectorate, NNPC CBN Annual Report and Statement of Account.

It is perhaps worth noting that by the year 2007, Nigeria realized a whooping sum of \#29.8 trillion naira, much of which was squandered on white elephant projects leading to slow rate of economic growth. A pointer to the squandering of the country's wealth could be seen in the deplorable conditions of roads in Nigeria.

Between 1999 and 2003 the government claimed to have spent over \#300billions on road construction. Today, in Nigeria, the stark paradox of the Nigerian experience is evident in the collapse of infrastructure in virtually every sphere of national life.
The energy sector is another embarrassing story. An estimated 16billion was spent by the Obasanjo administration between 2000 and 2007, but curiously as more money is sunk into the sector, power generation continues to dwindle. In a country that thrives on its oil wealth, petrol for local consumption is imported at $100 \%$ as successive regimes have failed to make the country's refineries work.

Perhaps the greatest steps that can be taken to make the country gain from its oil wealth is for government to seriously tackle corruption. 
Table 3: Comparison of Five Basic Development Indices among Ten Selected African Countries

\begin{tabular}{|l|l|l|l|l|l|l|}
\hline s/n & COUNTRY & $\begin{array}{l}\text { GPD per a person, } \\
\text { purchasing power- } \\
\text { parity }\end{array}$ & $\begin{array}{l}\text { Government } \\
\text { Effectiveness } \\
{[\%]}\end{array}$ & $\begin{array}{l}\text { Political } \\
\text { Stability } \\
{[\%]}\end{array}$ & $\begin{array}{l}\text { Anti- } \\
\text { Corruption } \\
{[\%]}\end{array}$ & $\begin{array}{l}\text { Rule } \\
\text { Law } \\
{[\%]}\end{array}$ \\
\hline 1 & Nigeria & $\$ 1,500$ & 16.6 & 3.8 & 5.8 & 8.1 \\
\hline 2 & DR Congo & $\$ 700$ & 1.9 & 1 & 2.9 & 1.9 \\
\hline 3 & Liberia & $\$ 900$ & 6.6 & 12.5 & 20.4 & 11 \\
\hline 4 & Kenya & $\$ 1,200$ & 28 & 15.4 & 16 & 15.7 \\
\hline 5 & Mauritius & $\$ 13,700$ & 71.6 & 79.3 & 66.5 & 75.7 \\
\hline 6 & South Africa & $\$ 13,300$ & 76.8 & 44.2 & 70.9 & 58.6 \\
\hline 7 & Botswana & $\$ 10,900$ & 73.9 & 93.3 & 78.2 & 67.1 \\
\hline 8 & Angola & $\$ 4,500$ & 10.9 & 28.8 & 8.7 & 7.1 \\
\hline 9 & Senegal & $\$ 1,800$ & 47.4 & 37.5 & 41.7 & 45.7 \\
\hline 10 & Rwanda & $\$ 1,600$ & 39.8 & 27.4 & 55.8 & 34.3 \\
\hline & $\begin{array}{l}\text { Sub-Saharan } \\
\text { Africa }\end{array}$ & $\begin{array}{l}\text { World Average } \\
\text { Average }\end{array}$ & 27.2 & 35.6 & 30.3 & 28.8 \\
\hline
\end{tabular}

Source: World Fact Book and World Bank (2001)

It is clear from table 3 that Nigeria has failed to utilize its petro-dollars earned from oil fortunes to improve the welfare of Nigerians. It is quite embarrassing that the country trails far behind Mauritius, South Africa, Botswana, Angola, Senegal and Rwanda [in descending order] in purchasing power parity [GPD]. The GPD of an average Nigerian stood at $\$ 1,500$, compared with the world's average of $\$ 10,200$ in 2000. Amongst the ten selected African countries, only Mauritius [\$13,700], South Africa $[\$ 13,300]$ and Botswana $[\$ 10,900]$ exceeded the world's average of $\$ 10,200$. As it is today, over 70 percent of Nigerian households are poor; under five years of age mortality is 187 out of 1000 live births; illiteracy level is 41 percent; life expectancy is 52years, while the proportion of the population below poverty line is 43 percent [Vincent, Ola. former governor of CBN]. Recently a more pathetic picture was painted by the director general of Nigerian Economic Summit Group [NESG] who noted that inflation rate is at 14.8 percent and per capita income is a paltry $\$ 300$.' He explained that 'inflation rate is at 14.8 percent and per capita income is a paltry $\$ 300$ '. Furthermore, he added that 'there is a growing imbalance of trade and payment in the face of decaying infrastructure,'

The low ranking of the country in terms of political stability, rule of law, government effectiveness and anti-corruption (particularly in the eight years of Obasanjo's tenure as revealed by the on going probe into the activities of NIPPpower sector by the lower house) probably explains how we as a nation squandered thirty trillion naira earned from sale of crude oil in five decades. 


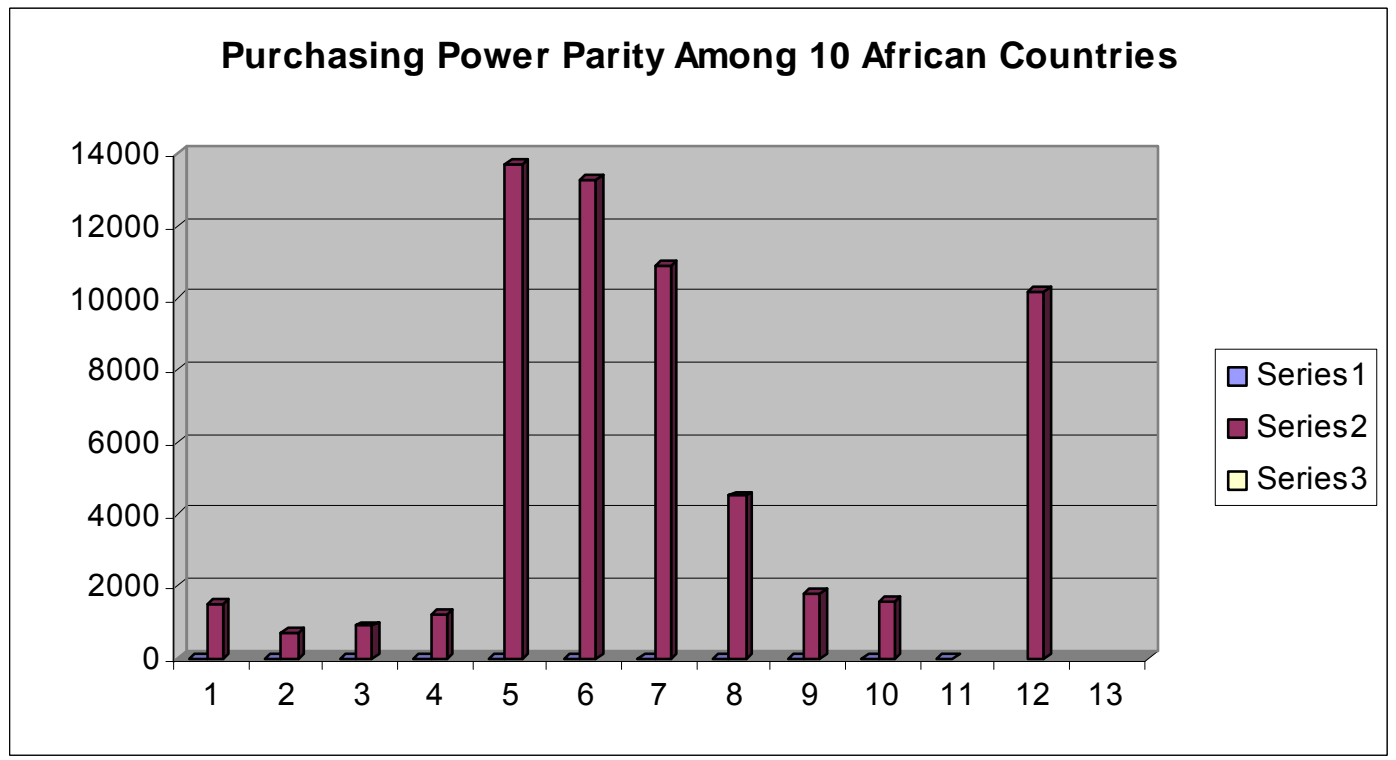

Fig. 3: Comparison of Four Basic Development Indices among Ten Selected African Countries Legend;

\begin{tabular}{|c|c|c|c|c|}
\hline 1 & Nigeria & 2 & DR Congo & Liberia 4 \\
\hline 5 & Mauritius & 6 & South Africa & 7 Botswana \\
\hline & Angola & & & \\
\hline
\end{tabular}

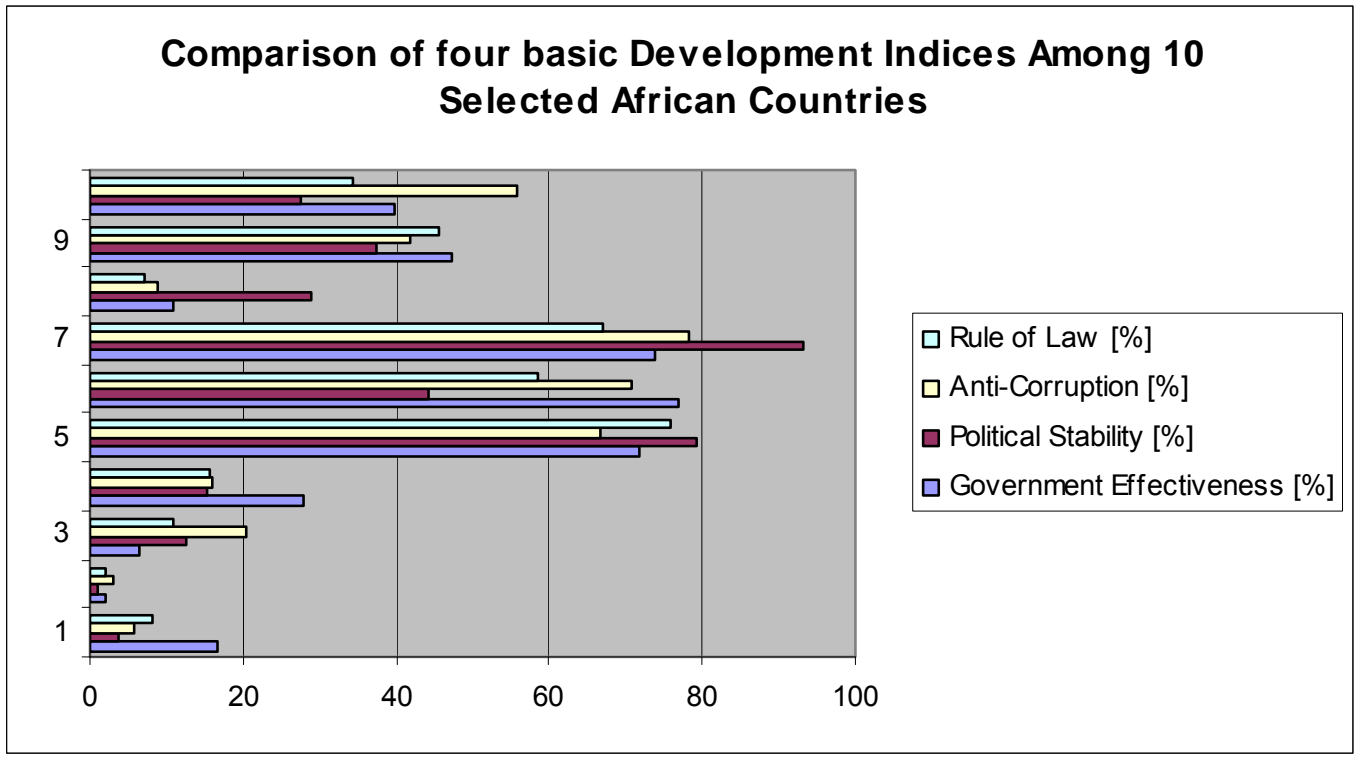

Fig. 4: Purchasing Power Parity among Ten African Countries

\section{Legend;}

1 Nigeria 2 Liberia $3 \quad$ Kenya 4 Mauritius

5 South Africa 6 Botswana 7 Angola 8 Senegal

9 Rwanda 10 World's Average 
Nigeria scored $16.6 \%, 3.8 \%, 5.8 \%$, and $8.1 \%$ in government effectiveness, political stability, anti-corruption and rule of law respectively. These scores provided above in percentages are far below the sub Saharan Africa's average of $27.2,35.6,30.3$ and $28.8 \%$ respectively.

Closely related to this is the lack of alternative sources of revenue. Some other nations use their oil wealth to improve other sectors of their economy, but the situation has been different with Nigeria. Even when there are other alternatives to oil waiting to be explored, the whole attention has been on oil wealth.

The low scores in purchasing power/individual [fig4] in the country may be due largely to a very weak industrial/manufacturing base [table 4].

As at 2003, the manufacturing sector in Nigeria contributed only 2 percent of the gross domestic product [GDP]. The situation is not any better today as the country failed to invest in the downstream sector of the petroleum industry.

Table 4: Economic Indicators as at 2003

\begin{tabular}{|l|l|l|l|l|}
\hline Parameters & Brazil & Mexico & Ghana & Nigeria \\
\hline Population[m] & 184.1 & 105.0 & 20.8 & 132.8 \\
\hline GDP[US\$billions] & $\$ 1379$ & $\$ 942.2$ & $\$ 44.9$ & $\$ 43.4$ \\
\hline GDP per capita & $\$ 7600$ & $\$ 9,000$ & $\$ 2,200$ & $\$ 800$ \\
\hline GDP -Agriculture & $8.2 \%$ & $4.0 \%$ & $34.7 \%$ & $41.2 \%$ \\
\hline GDP -Industries & $37.8 \%$ & $26.3 \%$ & $24.9 \%$ & $15.7 \%$ \\
\hline GDP-Manufacturing & $20.5 \%$ & $18.9 \%$ & $9.4 \%$ & $2.0 \%$ \\
\hline Service & $53.9 \%$ & $69.7 \%$ & $40.3 \%$ & $43.1 \%$ \\
\hline Ave. growth rate & $0.1 \%$ & $1.2 \%$ & $4.8 \%$ & $3.4 \%$ \\
\hline Inflation rate & $9.3 \%$ & $4.0 \%$ & $26.4 \%$ & $11.7 \%$ \\
\hline
\end{tabular}

SOURCE: Afroworks Analysis White Paper,( 2003).

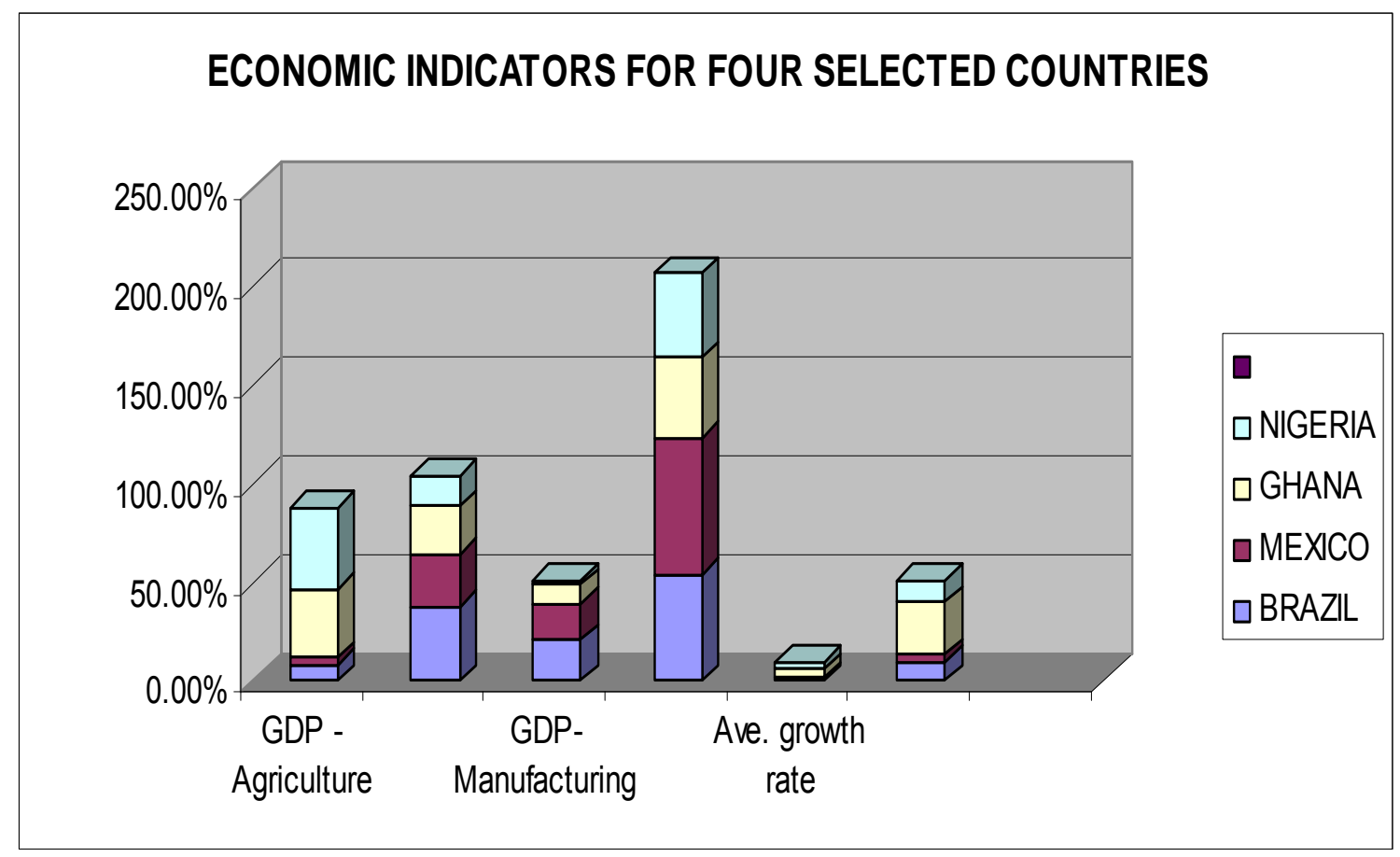

Fig.5: Economic Indicators As At 2003 


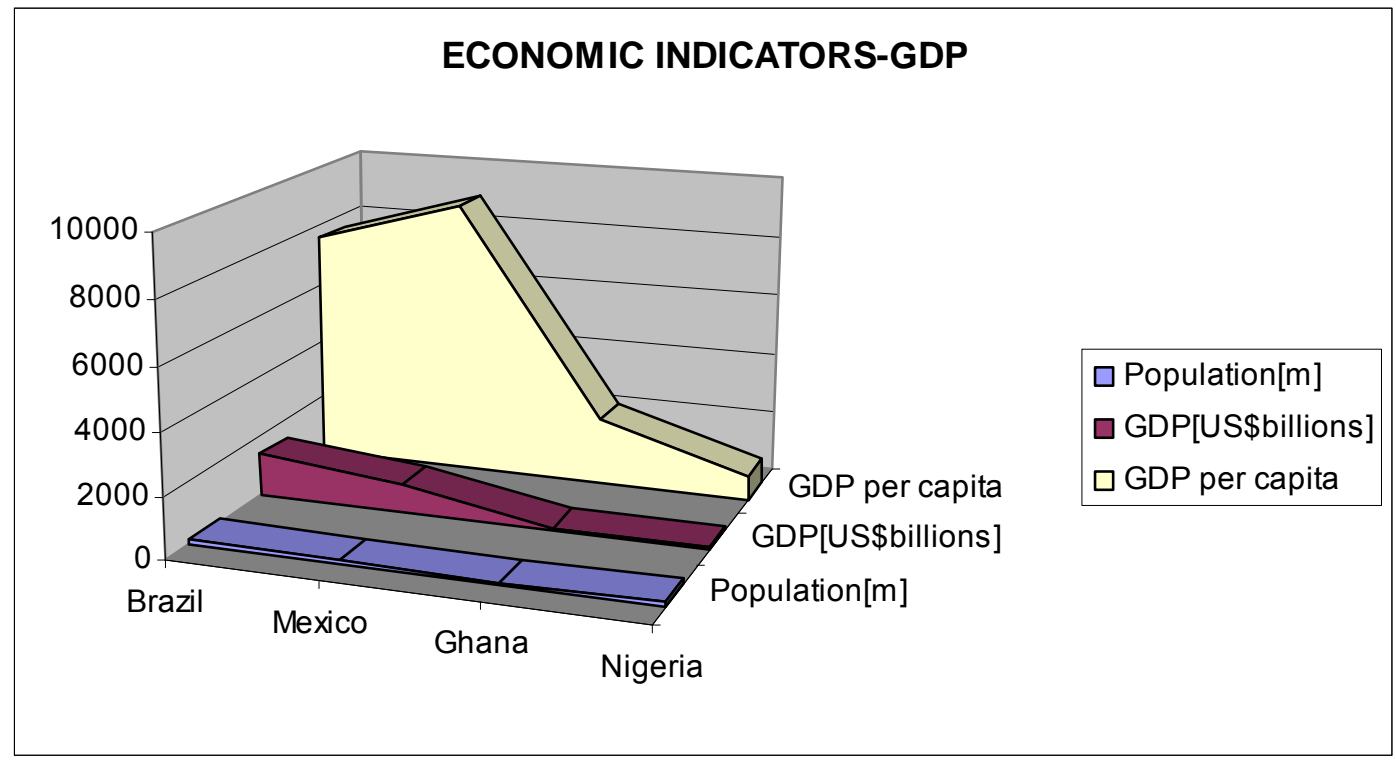

Fig. 6: Comparison of Economic Indicators in Four Countries

The obvious conclusion to draw from the two graphs are;

- countries with a manufacturing sector that produced greater than $15 \%$ of GDP have medium to high per capital.

The present administration under Yar'adua intends to tackle this problem by adopting the concept of industrial clusters as an industrial development strategy. It will bring about the creation of a community of infrastructure and other amenities in identified locations

The cluster concept would operate at five different levels -

\section{- $\quad$ free trade zone \\ - $\quad$ industrial parks \\ - $\quad$ industrial clusters \\ - $\quad$ enterprise zone \\ - incubators}

The free trade zone for instance, will serve as the oasis of economic activities and will be situated in close proximity to seaports and international airports[outside the territory of the customs].To attract foreign direct investments, duties will not be collected on exports of finished goods.

\section{$\bullet$}

On the other hand, the industrial parks would consist of mega parks covering areas of not less than $30-50 \mathrm{~km}^{2}$ for large manufacturing companies with high value addition in the production of finished products. The parks would be located in each of the six geopolitical zones of Nigeria. In a similar fashion, the industrial cluster would cover area of between 100 and1,000 hectares for the organized private sector. Logically, the economy will be private sector driven once the privatization exercise is concluded a good example is Brazil.

\section{RECOMMENDATION/CONCLUSION}

In conclusion, for Nigeria to grow it must transit from extraction based-economies and strategically develop the manufacturing sector of the economy. It will enjoy the following advantages; manufacturing provides higher paying jobs than the agricultural and service sectors, manufacturing reduces dependence on imports which drains foreign exchange earning of the country. Also, the agricultural sector should be revisited. It is true that the oil wealth was initially well applied towards the development of the country. Overtime, successive governments began to mismanage it and a situation like this has given rise to other contemporary oil nations overtaking Nigeria. The consequence is that the early gains of oil disappeared in the face of declining quality of general infrastructure across the country. The growing reliance of the country on oil and gas alone may undermine the democratic structure such as rule of law, political 
stability (as in the case of militancy in the Niger Delta region), government effectiveness and the fight against corruption

\section{REFERENCES}

Amu, L., 1983. A Review of Nigeria's Oil Industry. NNPC Publication. Lagos, Nigeria.

Afroworks, 2003. 'Why Manufacturing is a Matter of Life or Death in Nigeria' Analysis white paper presented at International Trade Expo at Nicon Hilton Hotel, Abuja, 2003.

Bulte, E.H. Damania R, Deacon, R.T., 2005. 'Resource Intensity, Institutions and Development.' World Development 33[7] ; 1029-1044.

CBN, 2007. CBN Annual report, published by the CBN, Lagos.

Chigbo, M., 2009. 'The Cartels behind Nigeria's Illegal Refineries' Newswatch Magazine January 19, 2009. Pp.16-25

Eni, H., 2008. 'Growing with the Cartel' Newswatch Magazine, Feb, 182008 pp.22-26.

Humphreys, M. Sachs, J.D. and Stiglitz J. E., 2007. Escaping the Resource Curse. Columbia University Press. Columbia.

Kaldor, M. Karl, T.L. and Said Y., 2007. Oil Wars. Pluto Press.

NNPC, 2008. Annual report and statement of account published by the Inspectorate div. Lagos
Sachs, J Warner A., 2003. 'The Curse of Natural Resources'. Eur Econ Rev. 45; 827-838.

Ogunlawo, A., 2008. 'Nigeria before Oil' Newswatch Magazine, Feb. 18 2008. pp 16-19.

Ross, M.L., 1999. The Political Economy of the Resource Curse. World Polit. 51[2];297322.

Shaxson, N., 2007. Poisoned Wells; The Dirty Politics of African Oil Palgrave, MacMillan, London.

Stevens, P., 2003. Resource Impact; curse or blessing? A literature survey. J. Energy Lit. ix [1] ; 3-42.

Stevens, P., 2008. Environmental Economics and Environmental and Resource Management. Editor Cleveland. C.J.

Stevens, P., 2008. 'Resource Curse' In Encyclopedia of Earth. Eds. Cutler. J Cleveland [Washington DC; Environmental Information] Coalition, National Council for Science and the Environment.

$<$ http;/www.eoearth.org/article/Resource curse $>$

Usman, S., 2008. 'Why Nigeria Remains Poor Despite Being Rich' Newswatch Magazine, Feb. 182008 pp.32-36.

World Bank, 2001. World Fact Book published by the World Bank, New York. 